\title{
Serum interleukin-6, interleukin -10, tumor necrosis factor -alpha, neopterin and plasma soluble urokinase plasminogen activator receptor levels in the patients with pandemic H1N1 influenza infection
}

\author{
Hasan Irmak ${ }^{1}$, Mustafa Karahocağil2, Salih Cesur ${ }^{1}$, Yasemin Fidan $^{3}$, Sema Özdamar ${ }^{3}$, Erdem Karabulut ${ }^{4}$, \\ Hayrettin Akdeniz², Ali Pekcan Demiröz ${ }^{1}$ \\ ${ }^{1}$ Ankara Training and Research Hospital, Clinic of Infectious Diseases and Clinical Microbiology, Ankara, Turkey \\ ${ }^{2}$ Van Yüzüncü Yal University, Faculty of Medicine, Department of Infectious Diseases and Clinical Microbiology, Van, Turkey \\ ${ }^{3}$ Ankara Training and Research Hospital, Clinic of Biochemistry and Clinical Biochemistry, Ankara, Turkey \\ ${ }^{4}$ Hacettepe University, Faculty of Medicine, Department of Bioistatistics, Ankara, Turkey
}

\begin{abstract}
Objective: This study aims to investigate the clinical importance of serum interleukin (IL) 6, IL-10, tumor necrosis factor alpha (TNF-alpha), neopterin, and plasma soluble urokinase plasminogen activator receptor (suPAR) levels in patients with pandemic H1N1 influenza infection and outpatients diagnosed with upper respiratory infections.
\end{abstract}

Materials and Methods: Twenty-six inpatients with H1N1 infection confirmed by clinical findings and polymerase chain reaction (PCR) test 30 outpatients diagnosed with upper respiratory infections, and 24 healthy individuals without any complaints were included. Serum IL-6, IL-10, TNF-alpha, neopterin levels and plasma suPAR levels were compared between the patients groups and the 24 healthy controls. Serum IL-6, IL-10, TNF-alpha, neopterin levels and plasma suPAR levels were determined through the enzyme-linked immunosorbent assay (ELISA) as per manufacturer's instructions.

Results: The median serum IL-6, IL-10, TNF-alpha, neopterin, and plasma suPAR levels were $27.8 \mathrm{ng} / \mathrm{ml}, 9.29 \mathrm{ng} / \mathrm{ml}$, $11.04 \mathrm{ng} / \mathrm{ml}, 8.82 \mathrm{ng} / \mathrm{ml}$ and $5.64 \mathrm{ng} / \mathrm{ml}$, respectively in inpatients with H1N1. In 30 outpatients diagnosed with upper respiratory infections, the median serum IL-6, IL-10, TNF-alpha, neopterin, and plasma suPAR levels were $7.24 \mathrm{ng} / \mathrm{ml}$, $1.9 \mathrm{ng} / \mathrm{ml}, 19.74 \mathrm{ng} / \mathrm{ml}, 4.37 \mathrm{ng} / \mathrm{ml}$ and $3.33 \mathrm{ng} / \mathrm{ml}$, respectively.

In healthy individuals, the mean IL-6, IL-10, TNF-alpha, neopterin, and plasma suPAR levels were $97 \mathrm{ng} / \mathrm{ml}, 0.16 \mathrm{ng} / \mathrm{ml}$, $4.46 \mathrm{ng} / \mathrm{ml}, 2.38 \mathrm{ng} / \mathrm{ml}, 1.65 \mathrm{ng} / \mathrm{ml}$, respectively.

In inpatients with H1N1, serum IL-6, IL-10, neopterin levels were significantly higher than those of outpatients diagnosed with upper respiratory infections. In outpatients with upper respiratory infections, serum TNF-alpha levels were higher than in inpatients with $\mathrm{H} 1 \mathrm{~N} 1$ infection as confirmed by laboratory findings (PCR).

In outpatients, serum IL-6, IL-10, TNF-alpha, neopterin, and plasma suPAR levels were significantly higher from those in the control group.

In patients with influenza A (H1N1) infection, serum cytokine levels and plasma suPAR levels were significantly higher from healthy individuals.

Conclusion: Serum IL-6, IL-10, TNF-alpha, neopterin, and plasma suPAR levels may be used as clinical follow-up markers in patients with H1N1 infection. J Microbiol Infect Dis 2015;5(3): 119-124

Key words: Pandemic influenz A (H1N1), cytokines, soluble urokinase plasminogen activator receptor (suPAR), diagnostic value.

Correspondence: Salih Cesur, Ankara Training and Research Hospital, Clinic of Infectious Diseases and Clinical Microbiology.

Email: scesur89@yahoo.com

Received: 29 January 2015, Accepted: 06 May 2015

Copyright (C) Journal of Microbiology and Infectious Diseases 2015, All rights reserved 


\section{Pandemik İnfluenza A (H1N1) Enfeksiyonu Olan Hastalarda Serum IL-6, IL-10, TNF-alfa, neopterin ve plazma solubl ürokinaz plasminojen aktivatör reseptörü düzeylerinin klinik önemi}

\section{ÖZET}

Amaç: Bu çalışmada, klinik ve laboratuvar bulgularıyla kesin pandemic influenza A (H1N1) enfeksiyonu tanısı konan yatan hastalar, üst solunum yolu enfeksiyonu enfeksiyonu tanısı konan poliklinik hastlarında serum IL-6, IL-10, TNF-alfa, neopterin düzeyleri ve plazma solubl ürokinaz plazminojen aktivatör reseptörü (suPAR) düzeyinin klinik öneminin belirlenmesi amaçlandı.

Yöntem: Çalışmaya influenza A (H1N1) enfeksiyonu tanısı klinik ve laboratuvar testiyle (polimeraz zincir reaksiyonu: PZR) tanısı konan 26 yatan hasta, üst solunum yolu enfeksiyonu (akut sinüzit, akut tonsillofarenjit, akut nazofarenjit vb.) tanısı konan 30 poliklinik hastası ve hiçbir yakınması olmayan 24 sağlıklı birey dahil edildi.

Serum IL-6, IL-10, TNF-alfa, neopterin düzeyleri ve plazma suPAR düzeyi ELISA yöntemiyle üretici firmanın önerileri doğrultusunda belirlendi. İstatistiksel değerlendirmede Kruskal- Wallis, Mann-Whitney U testi ve Ki-kare testleri kullanıldı.

Bulgular: Influenza A (H1N1) enfeksiyonu olan yatan hastalarda serum IL-6, IL-10, TNF-alfa, neopterin düzeyleri ile plazma suPAR düzeyleri median değeri sırasıyla; $27,8 \mathrm{ng} / \mathrm{ml}, 9,29 \mathrm{ng} / \mathrm{ml}, 11,04 \mathrm{ng} / \mathrm{ml}, 8,82 \mathrm{ng} / \mathrm{ml}, 5,64 \mathrm{ng} / \mathrm{ml}$ olarak belirlendi.

Üst solunum yolu enfeksiyonu tanısı konan poliklinik hastalarında serum IL-6, IL-10, TNF-alfa, neopterin düzeyleri ve plazma suPAR düzeyi median (ortanca) değeri sırasıyla; 7,24 ng/ml, 1,9 ng/ml, 19,74 ng/ml, 4,37 ng/ml, 3,33 ng/ml idi.

Sağlıklı bireylerde ise serum IL-6, IL-10, TNF-alfa, neopterin düzeyleri ve plazma suPAR düzeyi median değeri sırasıyla; $0,97 \mathrm{ng} / \mathrm{ml}, 0,16 \mathrm{ng} / \mathrm{ml}, 4,46 \mathrm{ng} / \mathrm{ml}, 2,38 \mathrm{ng} / \mathrm{ml}, 1,65 \mathrm{ng} / \mathrm{ml}$ olarak belirlendi.

İnfluenza A (H1N1) enfeksiyonu tanısı konan yatan hastalarda serum IL-6, IL-10, neopterin düzeyleri, üst solunum yolu enfeksiyonu tanısı konan poliklinik hastalarınkınden istatistiksel olarak anlamlı yüksekti. Üst solunum yolu enfeksiyonu tanısı konan poliklinik hastalarında serum TNF-alfa düzeyleri H1N1 tanısı konan yatan hastalardan daha yüksekti.

Üst solunum yolu enfeksiyonu tanısı konan poliklinik hastalarında, serum IL-6, IL-10, TNF-alfa, neopterin düzeyleri ile plazma suPAR düzeyleri kontrol grubundan anlamlı oranda yüksekti.

İnfluenza A (H1N1) enfeksiyonu tanısı alan yatan hastalarda serum IL-6, IL-10, neopterin ve plazma suPAR düzeyi sağlıklı bireylere göre anlamlı yükseklik gösterdi.

Sonuç: Serum IL-6, IL-10, neopterin, TNF-alfa düzeyleri ve plazma suPAR düzeyi influenza A (H1N1) enfeksiyonu olan hastaların klinik izleminde kullanılabilir.

Anahtar kelimeler: Pandemik H1N1, sitokinler, solubl urokinaz plazminojen aktivatör reseptörü (suPAR) , tanısal değeri

\section{INTRODUCTION}

The H1N1 influenza pandemic occurred in 2009 and spread throughout the world. In some patient groups, it was reported that the pandemic influenza (pH1N1) infection affected 20 to $40 \%$ of individuals and caused an increased hospitalization rate and also death.

In the USA, by April 2010, it was reported that 195,000 to 403,000 individuals were hospitalized and 8,807 to 18,300 individuals died due to H1N1

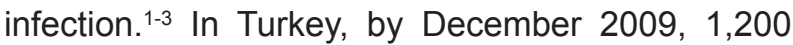
confirmed $\mathrm{H} 1 \mathrm{~N} 1$ cases were reported. It was reported that 20 cases died and 19 cases recovered with chronic diseases including one pregnant patient. ${ }^{4,5}$

In addition, the infection may cause upper respiratory tract infection in many patients, while it may also cause lower respiratory tract infection such as pneumonia in certain cases. Compared to seasonal influenza, H1N1 may present severly in young adults and healthy individuals. Young adults, pregnant women, puerperants, and infants are more susceptible to the H1N1 infection. ${ }^{1,6}$ The incidence of $\mathrm{H} 1 \mathrm{~N} 1$ infection is higher in ages 15 to 19 and lower in 65 years and older. ${ }^{6}$

As it has a mortality rate of approximately 14 to $46 \%$ in 9 to $34 \%$ for hospitalized patients due to respiratory insufficiency, patients must remain in intensive care. Similar to the H5N1 infection, significant adult respiratory distress syndrome (ARDS) and hemophagocytosis may present.

H1N1 can trigger a massive inflammatory response and can cause fever, damage in lung tissue and other vital tissues and result in death, eventually. It can adversely affect pulmonary immune pathology. Globally, more than 10,000 people died from the 2009 outbreak of $\mathrm{H} 1 \mathrm{~N} 1{ }^{1}$ 
The pathogenesis of fatal influenza infections still remains unclear and, therefore, management strategies also remain unclear.

When progressive pneumonitis develops due to the $\mathrm{p} \mathrm{H} 1 \mathrm{~N} 1$ infection, it is still unclear, if it is the result of increased seasonal influenza virus factors or of the vigorous induction of in vitro cytokine response by the virus. In several studies, it has been reported that during a $\mathrm{p} \mathrm{H} 1 \mathrm{~N} 1$ infection an excessive inflammatory cytokine response develops and certain cytokines and indicators increase. 1,7-12 $^{2}$

In this study, we aimed to determine the diagnostic value of serum IL-6, IL-10, TNF-alpha, neopterin levels and plasma soluble urokinase plasminogen activator receptor (suPAR) levels in patients with H1N1 infection and in patients with upper respiratory infections.

\section{MATERIALS AND METHODS}

This study was performed in Ankara Training and Research Hospital. The inpatients with $\mathrm{H} 1 \mathrm{~N} 1$ were selected from Yüzüncü Yıl University, Faculty of Medicine Department of Infectious Diseases and Clinical Microbiology, while outpatients with upper respiratory infections were selected from Ankara Training and Research Hospital outpatient clinics of Infectious Diseases and Clinical Microbiology. Healthy subjects consisted of healthy adult volunteers. The cytokine levels were determined using the ELISA method at the Biochemistry Clinic of this hospital.

\section{Study population}

This study included 26 patients who were diagnosed with H1N1 infection by clinical and laboratory tests (real-time PCR) and 30 outpatients with upper respiratory infections. The control group consisted of 24 healthy disease-free individuals.

The laboratory diagnosis of the inpatients was confirmed at Refik Saydam Hıfzıssıhha Center in the Virology Reference Laboratory with real-time PCR. Outpatients with upper respiratory infections were diagnosed based on clinical findings (i.e., temperature of $37.5^{\circ} \mathrm{C}$ and higher, sore throat, nasal discharge, headache, fatigue). The study protocol was approved by the ethics committee of the Ankara Training and Research Hospital.

Plasma and serum samples were taken from all study participants within 24 to 48 hours after admission and they were stored at $-80{ }^{\circ} \mathrm{C}$ in a deep freezer.
Serum IL-6, IL-10, TNF-alpha, neopterin, and plasma suPAR levels were determined in both patient groups and control group based on the ELISA method.

\section{Statistical Analysis}

Statistical analysis was performed using the SPSS 15.0 (SPSS Inc., Chicago, IL, USA). The ShapiroWilk test was used to determine if the continuous variables were normally distributed. One-way variance of analysis (ANOVA) was performed to analyze normally and abnormally distributed data. The Kruskal-Wallis test was used to measure between group variance. When discrepancy was meaningful pairwise, a comparison was made with the Bonferroni-correctedMann-Whitney $U$ test. The chi-square test was used to analyze qualitative data. A $p$ value of $<0.05$ was considered statistically significant.

\section{RESULTS}

Among 26 patients who were diagnosed with an H1N1 infection, 18 were females and eight were males. Among 30 outpatients with upper respiratory infections, 12 were females and 18 were males. Of the control group, 10 were females and 14 were males. There was no significant difference in sex among the groups $(p=0.057)$.

The mean age was $39.47 \pm 11.9$ for outpatients, $39.12 \pm 13.3$ for inpatients and $42.17 \pm 9.7$ for the controls. There was not any significant difference in age among the groups $(F=0.50, p=0.609)$.

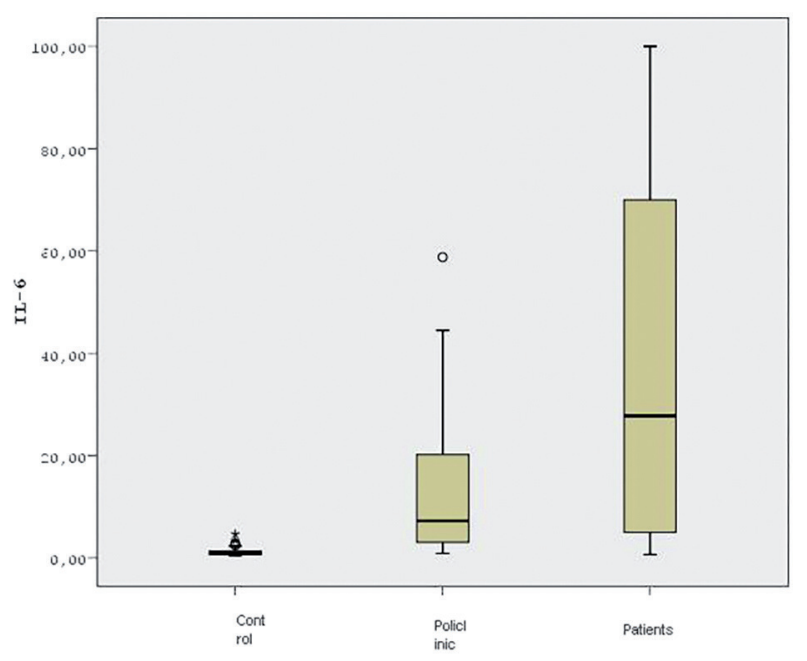

Figure 1. Serum IL-6 levels in patients, outpatients and control 


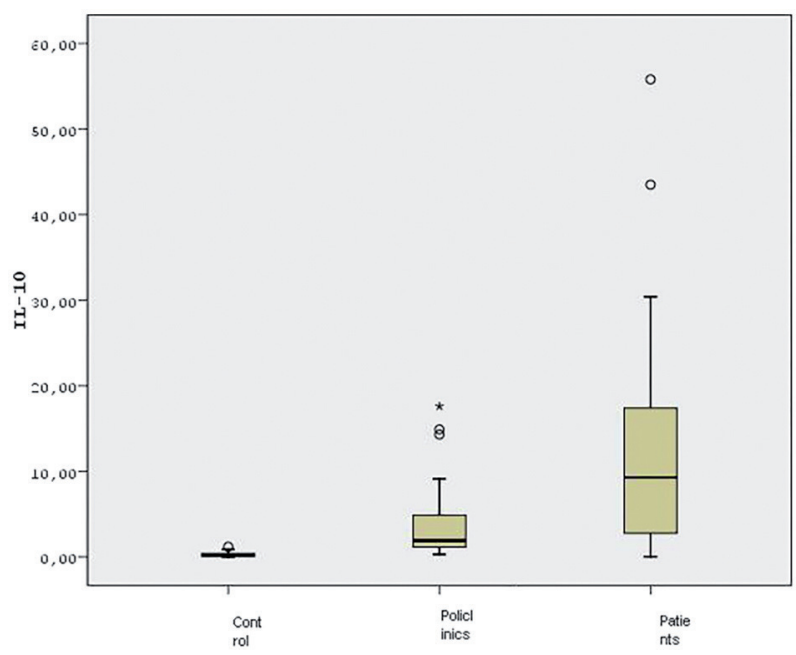

Figure 2. Serum IL-10 levels in patients, outpatients and control

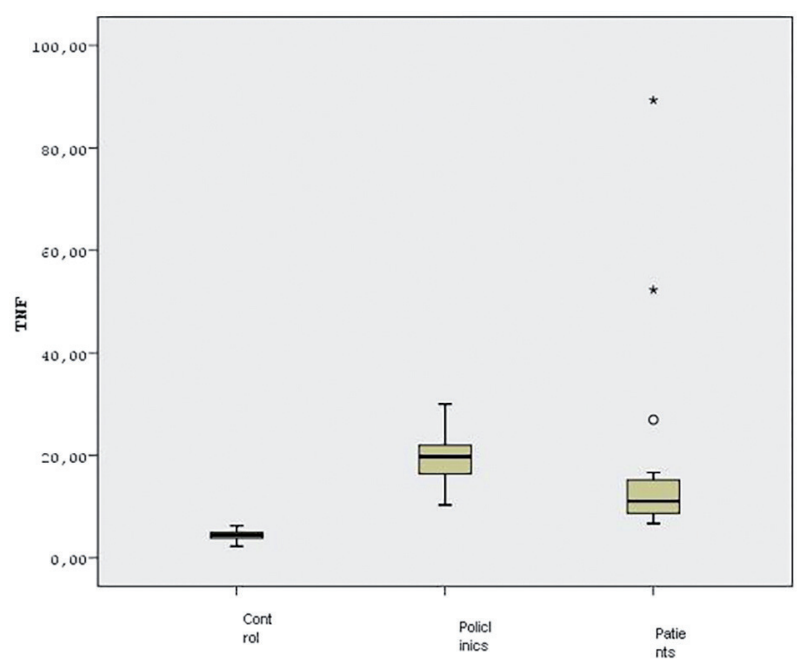

Figure 3. Serum TNF-alpha levels inpatients, outpatients and control group

All inpatients who was hospitalized in the ward had pneumonia and only five of the cases (19\%) needed to be treated in the intensive care unit. None of the inpatients or outpatients died. Among the groups, a statistically significant difference in cytokine levels was observed $(p<0.001)$.

Serum IL-6, IL-10, neopterin, and plasma suPAR levels were higher in inpatients diagnosed with pneumonia compared to the outpatients and the controls $(p<0.05)$. Serum TNF-alpha levels were higher in outpatients than the inpatients. There was no statistical difference in the cytokine levels of patients who were followed in the intensive care units and in the ward $(p<0.05)$. Both in outpatient and inpatients, serum cytokine levels were statistically significantly higher compared to the control group. The results are shown in Figures 1, 2, 3, 4, and 5.

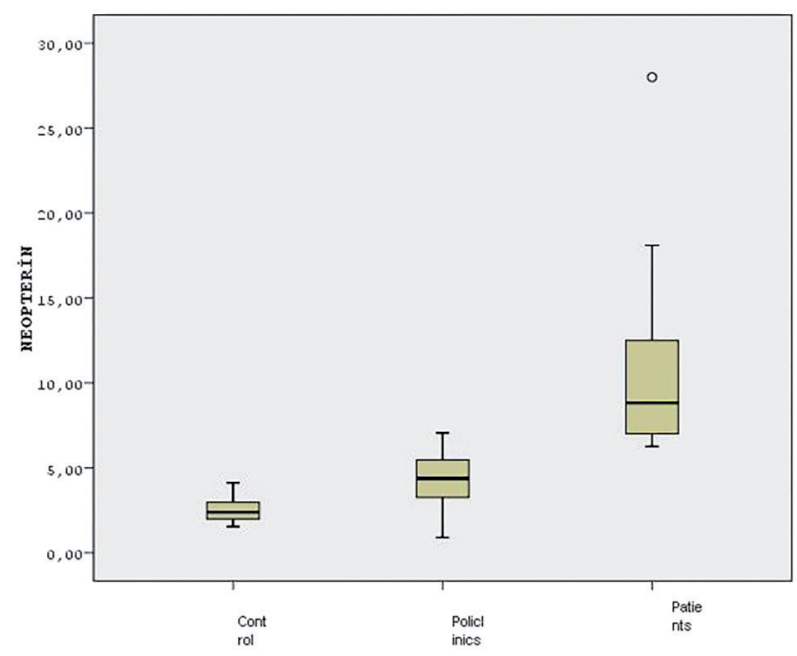

Figure 4. Serum neopterin levels inpatients, outpatients and control

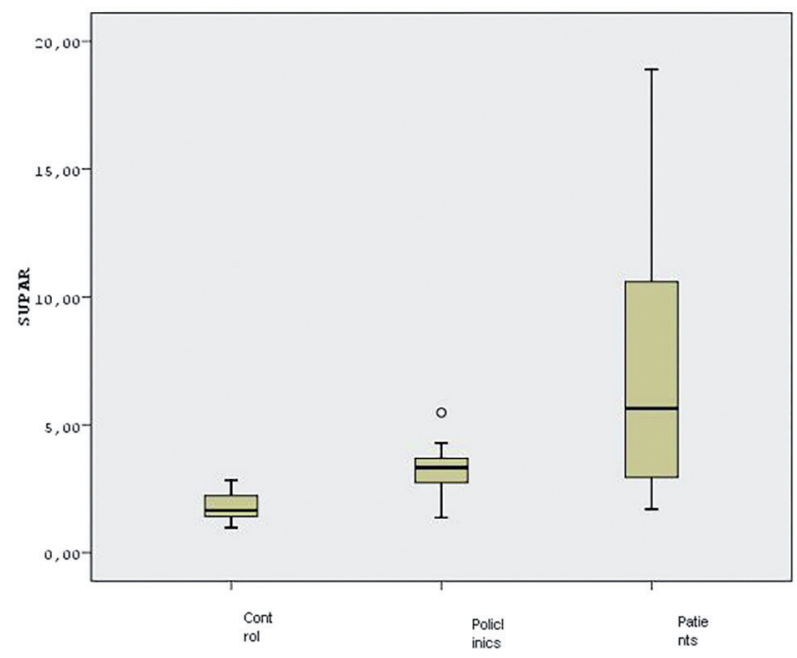

Figure 5. Serum suPAR levels in patients, outpatients and control

\section{DISCUSSION}

Pandemic H1N1 infection spread from Mexico in 2009 and it is a swine-originated influenza A virus which spread throughout the whole world. ${ }^{9}$ Severe diseases caused by the 2009 pandemic influenza $\mathrm{A} / \mathrm{H} 1 \mathrm{~N} 1$ virus were characterized by hypercytokinemia. However, the reason for the severe cytokine response was not exactly defined..$^{11}$ The human immune system naturally induces cytokine and che- 
mokines as a first defensive response to viruses. There were different results in the host cytokine profile for the pandemic influenza infection. ${ }^{6}$

Severe respiratory disease caused by pandemic influenza virus is related to viral replication and a host cytokine response..$^{11}$ In our study, 26 patients who were diagnosed with $\mathrm{H} 1 \mathrm{~N} 1$ infection had pneumonia and in five patients (19\%) were hospitalized in the intensive care unit. None of the hospitalized patients died. Serum cytokine levels and plasma suPAR levels were significantly different in hospitalized H1N1 patients and outpatients with upper respiratory infections compared to the control group. Except serum TNF-alpha, serum IL-6, IL-10, neopterin, and plasma suPAR levels in inpatients were higher than outpatients and the controls. TNF-alpha levels were also higher in outpatients compared to the inpatients. However, cytokine levels between the intensive care patients and the ward patients were not significantly different. Both outpatients and inpatients patients had statistically significantly higher cytokine levels, compared to the healthy controls.

In a study conducted by Lee et al., ${ }^{1} 63 \mathrm{p} \mathrm{H} 1 \mathrm{~N} 1$ laboratory-confirmed adults and 53 seasonal influenza patients were hospitalized. The authors evaluated patient plasma and compared 13 cytokine levels with flow cytometry and the ELISA method. The excessive activation of pro-inflammatory cytokines such as IL-6, IL-8, etc. were found in patients with H1N1 pneumonia and complicated by seasonal influenza infection. Increased pro-inflammatory cytokines, particularly IL-6, can be used for the estimation of intensive care requirement and they are linked to fever, tachypnea, dehydration, and long hospitalization stay.

Jost et al. ${ }^{12}$ reported that inflammatory cytokines such as IFN-Y and IL-2 plasma levels were lower and anti-inflammatory cytokines such as IL10 was higher in acute H1N1-infected patients. In another study carried out in China in H1N1-infected patients, Shen et al. ${ }^{13}$ reported that IL-6 and IFN-Y levels increased three days after the onset of infection symptoms in mildly infected patients. The authors reported that increased IL-6 levels particularly contributed to the development of serious lung inflammations and tissue damage. ${ }^{13-15}$

Similarly, Paquette et al. $^{10}$ reported that increased IL-6 levels in severe influenza A (H1N1) infection could determine the level of intensive care requirement and risk of death. On the other hand, Guo et al. ${ }^{6}$ studied 36 severe and 40 mild cases of $p$ H1N1 and reported that serum cytokines IL-2, IL-4,
IL-6, IL-10 and IFN-y levels were not significantly different compared to the healthy control groups and the serum CRP levels in mild and severe H1N1 infections were higher than in the control groups.

Mukherjee et al.16 reported that serum IL-8 and IL-1 levels in $\mathrm{p} \mathrm{H} 1 \mathrm{~N} 1$-infected patients were significantly lower than that of seasonal influenza-infected patients. The authors concluded that $\mathrm{p} \mathrm{H} 1 \mathrm{~N} 1$ infection induced the natural immune system's response in a powerful way.

Yu et al. ${ }^{9}$ studied $77 \mathrm{p} \mathrm{H} 1 \mathrm{~N} 1$-infected patients and 59 of them were mildly symptomatic and noninfluenza infected patients, while 26 of them were vaccinated with $\mathrm{H} 1 \mathrm{~N} 1$ vaccine and 26 of them were healthy individuals. This study showed that serum IL-2, IL-12, IFN- $\gamma$, IL-6, TNF- $\alpha$, IL-5, IL-10, IL-17, and IL-23 levels in mildly $p \mathrm{H} 1 \mathrm{~N} 1$-infectedcases were significantly higher than the other groups. In severe $\mathrm{p} \mathrm{H} 1 \mathrm{~N} 1$-infected patients, serum IL-6 and IL10 levels were also reported to be higher.

In another study, Hagau et al. ${ }^{7}$ included a total of 32 patients including 21 patients with confirmed H1N1 infection with acute respiratory distress syndrome (ARDS) and 11 mildly-infected patients. The study showed that a higher number of patients with ARDS related to $\mathrm{p} \mathrm{H} 1 \mathrm{~N} 1$ infection was susceptible to obesity and lymphocytopenia, whereas IL-12, IL-15, TNF- a, IL-6, IL-8 levels were higher than in the control group. The patients with ARDS related to an $\mathrm{H} 1 \mathrm{~N} 1$ infection had significantly higher serum IL-6, IL-8, IL-15 and TNF- a levels, compared to the milder patient group. In patients who died, the IL-6 and IL-15 levels were found to be higher on the admission day and three days after admission. Kim et al. ${ }^{17}$ compared cytokine levels in severely H1N1-infected patients to mild H1N1 infection in children and patients with pneumonia. In this study, the IL-10 and IFN- $\alpha$ levels in $\mathrm{H} 1 \mathrm{~N}$-infected patients were higher than in that of pneumonia patients and IL-6 levels were higher in severely H1N1-infected patients than in that of milder patients. Serum IL-10 levels in severely H1N1-infected patients with pneumonia were higher than in that of milder patients. Liu et al.7 reported increased TLR2, TLR3, TLR-9 releases in patients with $\mathrm{H} 1 \mathrm{~N} 1 .^{7}$ In addition, IL-2, IL6, IFN-gamma and TNF-alpha levels significantly increased, while IL-10 level decreased and IL-4 level remained unchanged. Meanwhile, Th1 lymphocyteinduced cellular immune response plays an important role in the modulation of the H1N1 infection.

In our study, we found a significant difference in serum IL-6 and IL-10 levels between the patient 
groups and controls, in consistent with previous study findings. ${ }^{1,7,9,10,16}$ For instance, the increase in serum TNF-alpha levels found to be similar with the Liu et al. study. ${ }^{7}$ To the best of our knowledge, no study on plasma suPAR and serum neopterin levels in patients with $\mathrm{H} 1 \mathrm{~N} 1$ infection is available in the literature; therefore, it sets our study apart from other studies.

However, there are some limitations to this study including lack of a proven microbiological diagnosis for the outpatients with an upper respiratory tract infection and not being able to study the consecutive serum cytokine levels (i.e., after the treatment) due to budgetary constraints. However, this study is the first study investigating plasma suPAR and neopterin levels in $\mathrm{H} 1 \mathrm{~N} 1$ - infected patients.

In conclusion, our study results suggest that serum IL-6, IL-10, TNF-alpha, neopterin levels and plasma suPAR levels might be used as clinical follow-up markers in patients with H1N1 infections.

\section{REFERENCES}

1. Lee N, Wong CK, Chan PK, et al. Cytokine response patterns in severe pandemic $2009 \mathrm{H} 1 \mathrm{~N} 1$ and seasonal influenza among hospitalized adults. PLoS One. 2011;6:e26050.

2. World Health Organization. Influenza, Available http://www. who.int/topics/ influenza/en. Accessed 2011 May, 1.

3. Shaw M, Uyeki TM, Zaki SR, et al. Clinical aspects of pandemic 2009 influenza $A(H 1 N 1)$ virus infection. N Engl J Med 2010; 362:1708-1719.

4. TC Sağlık Bakanlığı, Refik Saydam Hıfzıssıhha Merkezi Başkanlığı. Türkiye İnfluenza Sürveyans Raporu 2010-2011. (Turkish)

5. Maral I, Eskiocak M, Öner A. Hasuder Sağlık Raporu, 2012. (Turkish)
6. Guo X, Chen Y, Li X, et al. Dynamic variations in the peripheral blood lymphocyte subgroups of patients with 2009 pandemic H1N1 swine-origin influenza A virus infection. Virol J 2011;8:215.

7. Liu Y, Chen H, Sun Y, Chen F. Antiviral role of toll-like receptors and cytokines against the new $2009 \mathrm{H} 1 \mathrm{~N} 1$ virus infection. Mol Biol Rep 2012;39:1163-1172.

8. Hagau N, Slavcovici A, Gonganau DN, et al. Clinical aspects and cytokine response in severe $\mathrm{H} 1 \mathrm{~N} 1$ influenza $\mathrm{A}$ virus infection. Crit Care 2010;14:R203.

9. Yu X, Zhang $X$, Zhao $B$, et al. Intensive cytokine induction in pandemic $\mathrm{H} 1 \mathrm{~N} 1$ influenza virus infection accompanied by robust production of IL-10 and IL-6. PLoS One 2011;6:e28680.

10. Paquette SG, Banner D, Zhao Z, et al. Interleukin- 6 Is a Potential Biomarker for Severe Pandemic H1N1 Influenza A Infection. PLoS One 2012;7:e38214.

11. Almansa $R$, Anton $A$, Ramirez $P$, et al. Direct association between pharyngeal viral secretion and host cytokine response in severe pandemic influenza. BMC Infect Dis 2011;31;11:232.

12. Jost S, Quillay H, Reardon J, Peterson E. Changes in cytokine levels and NK cell activation associated with influenza. PLoS One 2011;6:e25060.

13. Shen HH, Hou J, Chen WW, et al. Immunologic changes during Pandemic (H1N1) 2009, China. Emerg Infect Dis. 2011; 17:1053-1055.

14. Hayden FG, Fritz R, Lobo MC, et al. Local and systemic cytokine responses during experimental human influenza $A$ virus infection. Relation to symptom formation and host defense. J Clin Invest 1998; 101:643-649.

15. Kaiser L, Fritz RS, Straus SE, et al. Symptom pathogenesis during acute influenza: interleukin- 6 and other cytokine responses. J Med Virol 2001;64:262-268.

16. Mukherjee S, Vipat VC, Mishra AC, et al. Pandemic (H1N1) 2009 influenza virus induces weaker host immune responses in vitro: a possible mechanism of high transmissibility. Virol J 2011; 8:140.

17. Kim YH, Kim JE, Hyun MC. Cytokine response in pediatric patients with pandemic influenza H1N1 2009 virus infection and pneumonia: comparison with pediatric pneumonia without H1N1 2009 infection. Pediatr Pulmonol 2011; 46:12331239. 